\title{
Rational Use of Medicine in the Treatment of Helminth Infection : A Mini Review
}

\section{Reqgi First Trasia*}

Parasitology Department, Faculty of Medicine, Universitas Sultan Ageng Tirtayasa, Indonesia

\begin{abstract}
Indonesia still has health problem, especially soil transmitted helminth. These helminths can cause deteriorate health, nutrition, intelligence and productivity of patients so causes a lot of losses economically. The aim of this article is to review the rational treatment of helminth infection. Albendazole, mebendazole, and pyrantel pamoate are the drugs recommended by the WHO. However, the uses of the three are different, especially for mass treatment or selective medicine. This review conclude that the three drugs are used according to the target patient's age with dosages and preparations that must be adjusted.
\end{abstract}

Keyword: Medicine, Soil transmitted helminth, worm infection, antihelminthic

Abstrak. Indonesia masih memiliki beberapa masalah kesehatan, salah satunya infeksi kecacingan. Kondisi ini dapat menyebabkan gangguan nutrisi, kesehatan, dan produktivitas sehingga banyak kerugian secara ekonomi. Tujuan dari artikel ini adalah untuk meninjau penggunaan obat rasional dalam pengobatan infeksi kecacingan. Albendazole, mebendazole, dan pirantel pamoate adalah obat yang direkomendasikan oleh WHO. Namun, penggunaan ketiganya berbeda, terutama untuk pengobatan massal atau pengobatan selektif. Tinjauan ini menyimpulkan bahwa ketiga obat tersebut harus digunakan sesuai dengan target usia pasien, serta dosis dan sediaan yang tepat.

Kata Kunci: Pengobatan, kecacingan, infeksi parasit, antihelminthic

Received 12 January 2021 | Revised 8 May 2021 | Accepted 15 May 2021

\section{Introduction}

Indonesia still has many diseases which are a health problem, one of which is helminthhelminth that are transmitted through soil, namely Ascaris lumbricoides Trichuris trichiura and Ancylostoma duodenale, Necator americanus,. These helminth cause deteriorate health, nutrition, intelligence and productivity of sufferers so economically causes a lot of losses. Helminth cause loss of carbohydrate and protein as well as blood loss, thus reduce the quality of human resources. The prevalence of helminth infection in Indonesia in general is still very high,

\footnotetext{
*Corresponding author at: Parasitology Department, Faculty of Medicine, Universitas Sultan Ageng Tirtayasa, Indonesia 
especially in remote are with poor sanitation. Helminth infection prevalence varies between $2.5 \%-62 \% .[1]$

Helminth affect intake (intake), digestion (digestive), absorption (absorption), and metabolism of food. Cumulatively, worm infection or helminth can cause harm to nutritional needs due to lack of calories and protein, and loss blood. Besides being able to hinder physical development, intelligence and work productivity, can reduce body resistance so it's easy contracted other diseases.[2]

Other losses due to worm infection have been calculated based on the effect from helminth that can be caused. Disability Adjusted Life Years (DALYs) is a mathematical method of calculating loss of productive time due to worm infection. DALYs can calculated by estimating some of the consequences of the worm disease, namely weak physical condition and attendance rate low school and high-risk worm sufferers easy infected with disease.[3]

Helminth is an environmental based disease hence attention to environmental sanitation needs to be increased. Actually, stomach worm infection will decrease and even get it be eliminated altogether if it is pursued for a clean lifestyle and healthy like washing hands with soap at five important times (after defecating, after cleaning a child who has defecated, before preparing food, before eating, after handling / touching animals), as well as managing food properly, clean environment, nutritious food, that is later it will be achieved by itself in development programs and poverty alleviation. When the economy is good, then it will build a better house, a healthier latrine, send the children to school to know more about health problems, buy radio and television so you can hear broadcasts about health education, so that it can change behavior towards clean and healthy lifestyle.[4]

Helminth control begins by reducing the prevalence worm infection by killing the helminth through medication to reduce the intensity of infection (the number of helminth per person), so that can improve health status. But infection treatment must be accompanied by efforts to have a clean and healthy lifestyle, sanitation environment and intake of nutritious food. For that it is necessary cross-program and cross-sector cooperation related to both government and the private sector, in order to establish sustainable communication so that there is a common understanding in helminth disease management either in the short term or long term. The aim of this article is to review the rational use of medicine in the treatment of helminth infection. [5]

\section{Treatment of Helminth Infection}

Albendazole and mebendazole are the drugs of choice for ascariasis. Albendazole dosage for adults and children older than 2 year is $400 \mathrm{mg}$ orally. WHO recommends a dose of $200 \mathrm{mg}$ for children 12-24 months of age. Mebendazole dosage for adults and children over 2 years of age, 
namely $500 \mathrm{mg}$. Albendazole and mebendazole is given a single dose. Pyrantel pamoate can used for ascariasis at a dose of $10-11 \mathrm{mg} / \mathrm{kg} \mathrm{BW}$ orally, the maximum dose is 1 gram. Operative action is required in an emergency due to adult helminth clogging the bile ducts and appendix. Ascariasis treatment should be accompanied by changes hygiene and healthy living habits and improved sanitation.[6]

The medication for hookworm infection is albendazole with single dose of $400 \mathrm{mg}$ orally or mebendazole 2 times $100 \mathrm{mg}$ per day or pyrantel pamoate $11 \mathrm{mg} / \mathrm{kg}$, maximum 1 gram per day. Mebendazole and pyrantel pamoate is given for 3 consecutive days. WHO recommend an albendazole dose of $200 \mathrm{mg}$ for older children 12-24 months. To increase the hemoglobin level is necessary given nutritious food intake and iron supplementation.[7]

Patient Treatment is carried out on each sufferer found by health workers or at service facilities health. Treatment is given to the population that results examination of the stool positive for Helminth. This treatment is carried out in health facilities for Patients who come for treatment themselves and positive stool microscopic examination results or examination results clinically tested positive for helminth. For cases with positive stool aged <2 years and pregnant women, can be given worm medicine with an adjusted dose. To children under five are given a syrup.[8]

\subsection{Albendazole}

Albendazole is a broad spectrum worm medicine. This medicines work by inhibiting energy generation worm so it dies. Albendazole also has an effect larvicide against $A$. lumbricoidesA.duodenale and T.trichiura.[9]

After oral administration, albendazole will start immediately experience the first-pass metabolism of the heart to be the active metabolite albendazole-sulfoxide. Drug absorption will increase when given with fatty foods. The half-life of albendazole is $8-12$ hours with peak plasma levels are reached within 3 hours.[10]

In adult patients and children 2 years of age it is given single dose $400 \mathrm{mg}$ orally. For severe ascariasis it can be given for 2 - 3 days. WHO recommends dosage $200 \mathrm{mg}$ for children between 12-24 months of age. Use that is not more than 3 days, almost free of side effects. Side effects are usually mild and lasts briefly, namely discomfort in the stomach, nausea, vomiting, diarrhea, headache, dizziness, difficulty sleeping and sluggish.[11]

Albendazol should not be given to sufferers who are have a history of hypersensitivity to class drugs benzimidazole and people with cirrhosis. In severe ascariasis, can occur erratic migration, namely hyperactivity A.lumbricoides that migrate to other places and causing serious complications such as blockage of the duct bile, appendicitis, intestinal obstruction and 
intestinal perforation accompanied by peritonitis. In patients with fever as well first trimester pregnant women. Treatment can be delayed if there is one contra indication above.[12]

\subsection{Mebendazole}

Mebendazole has the same mechanism of action with albendazole. After oral administration, less than $10 \%$ of the drug will absorbed then converted into metabolites that are not active with a half-life of 2-6 hours. Excretion especially through urine and to a lesser extent through bile. Absorption will increase when given with fatty foods.[13]

Dosage for adults and children over 2 years of age is 2 times $100 \mathrm{mg} /$ day, for 3 consecutive days for ascariasis, hookworm and trichuriasis. Before swallowed the tablet should be chewed first. Giving the short term is almost free from side effects, namely nausea, vomiting, diarrhea and abdominal pain of a mild nature. On high doses so that no systemic effect can occur agranulocytosis, alopecia, elevated liver enzymes and hypersensitivity. Contraindicated for pregnant women because found teratogenic effects in experimental animals. In children age under 2 years, need to be careful because of the data use was limited and seizures were reported. As with albendazole erratic migration can occur in severe ascariasis.[14]

\subsection{Pyrantel Pamoate}

Pyrantel pamoate is effective in ascariasis and hookworm. The drug acts as a neuromuscular blocking agent which causes the release of acetylcholine and inhibition of cocinesterase thus resulting spastic paralysis. The recommended dose is $10 \mathrm{mg}-11 \mathrm{mg} / \mathrm{kg} \mathrm{BW}$ orally, maximum 1 gram, not affected by food. Side effects are rare, mild and lasting glimpses include nausea, vomiting, diarrhea, stomach cramps, dizziness, drowsiness, headache, insomnia, fever, tired. Be careful in patients with impaired liver function, because it can increase serum amino transferase on a small number of sufferers who get pyrantel. Data use of drugs in pregnant women and children under 1 year are still limited, therefore the use for the group is not recommended.[15]

\section{Anthelmintic Dosage}

\subsection{Mass Drug Administration}

Drugs used in drug administration prevention of soil-transmitted helminth is albendazole or mebendazole, in chewable tablet dosage forms and syrup. Toddlers are given in the form syrup preparations, while for pre-school children and school age is given in tablet dosage form chew. The dosage of Albendazole used is as follows: for population aged >2 years - adults: $400 \mathrm{mg}$ as a single dose, while children aged 1 - 2 years: $200 \mathrm{mg}$ single dose. The drug Mebendazole can also be used in giving helminth preventive drugs, dosage single dose $500 \mathrm{mg}$ is used.[16] 


\subsection{Selective Medication}

Selective treatment is given to districts / cities which has a low prevalence according to the following table.[17]

Table 1. Type and Drug Dosage

\begin{tabular}{|c|c|c|c|c|c|c|}
\hline \multicolumn{3}{|c|}{ Albendazole } & \multicolumn{2}{|c|}{ Mebendazole } & \multicolumn{2}{|c|}{ Pyrantel pamoate } \\
\hline $\begin{array}{l}\text { Target } \\
\text { (age) }\end{array}$ & $\begin{array}{l}\begin{array}{l}\text { Dosage } \\
\text { (tab }\end{array} \\
400 \mathrm{mg} \text { ) }\end{array}$ & $\begin{array}{l}\text { Dosage } \\
(\mathrm{syr} \quad 200 \\
\mathrm{mg} / 5 \mathrm{ml})\end{array}$ & $\begin{array}{l}\text { Target } \\
\text { (age) }\end{array}$ & $\begin{array}{l}\begin{array}{l}\text { Dosage } \\
\text { (tab } \\
500 \mathrm{mg})\end{array}\end{array}$ & $\begin{array}{l}\text { Target } \\
\text { (age) }\end{array}$ & $\begin{array}{l}\text { Dosage (tab } \\
125 \mathrm{mg})\end{array}$ \\
\hline \multirow[t]{2}{*}{ 1-2 year } & \multirow{2}{*}{$\begin{array}{l}1 / 2 \text { tablet } \\
(200 \mathrm{mg})\end{array}$} & \multirow[t]{2}{*}{$5 \mathrm{ml}$} & \multirow[t]{2}{*}{ 1-2 year } & \multirow[t]{2}{*}{1 tablet } & 4-9 month & $1 / 2$ tablet \\
\hline & & & & & 9-12 month & 3/4 tablet \\
\hline \multirow{2}{*}{$2-5$ year } & \multirow{2}{*}{1 tablet } & \multirow{2}{*}{$10 \mathrm{ml}$} & \multirow{2}{*}{ 2-5 year } & \multirow{2}{*}{1 tablet } & 1-3 year & 1 tablet \\
\hline & & & & & 3-5 year & $1 \frac{1 / 2 \text { tablet }}{}$ \\
\hline$>5$ year & 1 tablet & $10 \mathrm{ml}$ & $>5$ year & 1 tablet & $>5$ year & $10 \mathrm{mg} / \mathrm{kgBB}$ \\
\hline Pregnant & 1 tablet & $10 \mathrm{ml}$ & Pregnant & 1 tablet & Pregnant & $10 \mathrm{mg} / \mathrm{kgBB}$ \\
\hline
\end{tabular}

\section{Conclusion}

Based on the above review, it can be concluded that both albendazole, mebendazole and pyrantel pamoate are aimed at different targeted treatments. Albendazole and mebendazole are more effective for mass treatment. While pyrantel pamoate is effective for selective treatment. The three drugs are used according to the target patient's age with dosages and preparations that must be adjusted.

\section{REFERENCES}

[1]. D. Glinz, K. D. Silué, S. Knopp, L. K. Lohourignon, K. P. Yao, P. Steinmann, L. Rinaldi, G. Cringoli, E. K. N'Goran, and J. Utzinger, "Comparing Diagnostic Accuracy of Kato-Katz, Koga Agar Plate, Ether-Concentration, and FLOTAC for Schistosoma mansoni and Soil-Transmitted Helminths," PLoS Neglected Tropical Diseases, vol. 4, no. 7, p. e754, Jul. 2010.

[2]. M. Mbong Ngwese, G. Prince Manouana, P. A. Nguema Moure, M. Ramharter, M. Esen, and A. A. Adégnika, "Diagnostic Techniques of Soil-Transmitted Helminths: Impact on Control Measures," Tropical Medicine and Infectious Disease, vol. 5, no. 2, p. 93, Jun. 2020.

[3]. G. Cringoli, L. Rinaldi, M. P. Maurelli, and J. Utzinger, "FLOTAC: new multivalent techniques for qualitative and quantitative copromicroscopic diagnosis of parasites in animals and humans," Nature Protocols, vol. 5, no. 3, pp. 503-515, Feb. 2010.

[4]. M. D. Lim, S. J. Brooker, V. Y. Belizario, F. Gay-Andrieu, J. Gilleard, B. Levecke, L. van Lieshout, G. F. Medley, Z. Mekonnen, G. Mirams, S. M. Njenga, M. R. Odiere, J. W. Rudge, L. Stuyver, J. Vercruysse, J. Vlaminck, and J. L. Walson, "Diagnostic tools 
for soil-transmitted helminths control and elimination programs: A pathway for diagnostic product development," PLOS Neglected Tropical Diseases, vol. 12, no. 3, p. e0006213, Mar. 2018.

[5]. V. Margarita, P. L. Fiori, and P. Rappelli, "Impact of Symbiosis Between Trichomonas vaginalis and Mycoplasma hominis on Vaginal Dysbiosis: A Mini Review," Frontiers in Cellular and Infection Microbiology, vol. 10, May 2020.

[6]. A. Spotin, H. R. Moslemzadeh, M. Mahami-Oskouei, E. Ahmadpour, M. Niyyati, S. H. Hejazi, F. Memari, and J. Noori, "Phylogeography, genetic variability and structure of Acanthamoeba metapopulations in Iran inferred by $18 \mathrm{~S}$ ribosomal RNA sequences: A systematic review and meta-analysis," Asian Pacific Journal of Tropical Medicine, vol. 10, no. 9, pp. 855-863, Sep. 2017.

[7]. S. Angelone-Alasaad, A. Molinar Min, M. Pasquetti, A. N. Alagaili, S. D’Amelio, F. Berrilli, V. Obanda, M. A. Gebely, R. C. Soriguer, and L. Rossi, "Universal conventional and real-time PCR diagnosis tools for Sarcoptes scabiei," Parasites \& Vectors, vol. 8, no. 1, Nov. 2015.

[8]. S. S. Y. Wong, R. W. S. Poon, S. Chau, S. C. Y. Wong, K. K. W. To, V. C. C. Cheng, K. S. C. Fung, and K. Y. Yuen, "Development of Conventional and Real-Time Quantitative PCR Assays for Diagnosis and Monitoring of Scabies," Journal of Clinical Microbiology, vol. 53, no. 7, pp. 2095-2102, Apr. 2015.

[9]. H. Gunawan, U. Sugiri, Nurhasanah, K. Makarti, and O. Suwarsa, "Oral Clindamycin as Drug of Choice for Scabies Patients with Secondary Bacterial Infections in West Java, Indonesia," American Journal of Infectious Diseases, vol. 14, no. 1, pp. 45-50, Jan. 2018.

[10]. P. Delaunay, A. L. Hérissé, L. Hasseine, C. Chiaverini, A. Tran, C. Mary, P. Del Giudice, P. Marty, M. Akhoundi, and T. Hubiche, "Scabies polymerase chain reaction with standardized dry swab sampling: an easy tool for cluster diagnosis of human scabies," British Journal of Dermatology, Aug. 2019.

[11]. M. Bae, J. Y. Kim, J. Jung, H. H. Cha, N.-Y. Jeon, H.-J. Lee, M. J. Kim, S. E. Chang, and S.-H. Kim, "Diagnostic value of the molecular detection of Sarcoptes scabiei from a skin scraping in patients with suspected scabies," PLOS Neglected Tropical Diseases, vol. 14, no. 4, p. e0008229, Apr. 2020.

[12]. S. Naz, F. R. Chaudhry, D. A. Rizvi, and M. Ismail, "Phylogenetic Analysis of Astigmatid Mites Sarcoptes scabiei and Dermatophagoides farinae using ITS-2 as a Genetic Marker," Life and Science, vol. 1, no. 2, p. 5, Apr. 2020.

[13]. C. Aubernon, V. Hédouin, and D. Charabidzé, "Les larves de diptères nécrophages en entomologie médico-légale: une histoire de température," médecine/sciences, vol. 33, no. 8-9, pp. 779-783, Aug. 2017.

[14]. S. Matuszewski, M. J. R. Hall, G. Moreau, K. G. Schoenly, A. M. Tarone, and M. H. Villet, "Pigs vs people: the use of pigs as analogues for humans in forensic entomology and taphonomy research," International Journal of Legal Medicine, vol. 134, no. 2, pp. 793-810, Jun. 2019.

[15]. H. Jordan and J. Tomberlin, "Abiotic and Biotic Factors Regulating Inter-Kingdom Engagement between Insects and Microbe Activity on Vertebrate Remains," Insects, vol. 8, no. 2, p. 54, May 2017.

[16]. K. Sukontason, S. Piangjai, S. Siriwattanarungsee, and K. L. Sukontason, "Morphology and developmental rate of blowflies Chrysomya megacephala and Chrysomya rufifacies in Thailand: application in forensic entomology," Parasitology Research, vol. 102, no. 6, pp. 1207-1216, Feb. 2008.

[17]. K. L. Sukontason, S. Sanit, T. Klong-klaew, J. K. Tomberlin, and K. Sukontason, "Sarcophaga (Liosarcophaga) dux (Diptera: Sarcophagidae): A flesh fly species of medical importance," Biological Research, vol. 47, no. 1, Apr. 2014. 